\title{
Sustainable Engineering and Eco Design
}

\author{
Chaouki Ghenai \\ Ocean and Mechanical Engineering Department, Florida Atlantic University \\ USA
}

\section{Introduction}

The material consumption in the United States of America now exceeds ten tones per person per year. The average level of global consumption is about eight times smaller than this but is growing twice as fast. The materials and the energy needed to make and shape them are drawn from natural resources: ore bodies, mineral deposits, and fossil hydrocarbons. The demand of natural resources throughout the 18th, 19th and early 20th century appeared infinitesimal (Ashby et al., 2007, Alonso et al., 2007, Chapman and Roberts, 1983, and Wolfe, 1984). There is also a link between the population growth and resource depletion (Ashby et al., 2007, Alonso et al., 2007, Chapman and Roberts, 1983, and Wolfe, 1984). The global resource depletion scales with the population and with per-capita consumption (Ashby et al., 2007, and Alonso et al., 2007). Per capita consumption is growing more quickly.

The first concern is the resource consumption. Speaking globally, we consume roughly 10 billion tones of engineering materials per year. We currently consume about 9 billion tones per year of hydrocarbon fuels (oil and coal). For metals, it appears that the consumption of steel is the number one ( $\sim 0.8$ billion tones per year) followed by aluminum (10 millions tones per year). The consumption of steel exceeds, by a factor of ten all other metals combined. Polymers come next: today the combined consumption of commodity polymers polyethylene (PE), polyvinyl chloride (PVC), polypropylene (PP) and polyethyleneterephthalate, (PET) begins to approach that of steel (see figure 1). The really big ones, though, are the materials of the construction industry. Steel is one of these, but the consumption of wood for construction exceeds that of steel even when measured in tones per year, and since it is a factor of 10 lighter, if measured in m3/year, wood totally eclipses steel. Bigger still is the consumption of concrete, which exceeds that of all other materials combined as shown in Figure 1. The other big ones are asphalt (roads) and glass.

The second concern is the energy and carbon release to atmosphere caused by the production of these materials as shown in Figure 2. This is calculated by multiplying the annual production by the embodied energy of the material ( $\mathrm{MJ} / \mathrm{Kg}$ - energy consumed to make $1 \mathrm{Kg}$ of material). During the primary production of some materials such as metals, polymers, composites, and foams the embodied energy is more than $100 \mathrm{MJ} / \mathrm{Kg}$ and the $\mathrm{CO} 2$ foot print exceeds $10 \mathrm{Kg}$ of CO2 per $\mathrm{Kg}$ of materials.

New tools are needed to analyze these problems (high resource consumption, energy use and $\mathrm{CO} 2$ emissions) best material based on the design requiment but also to reduce the environmental impacts. 


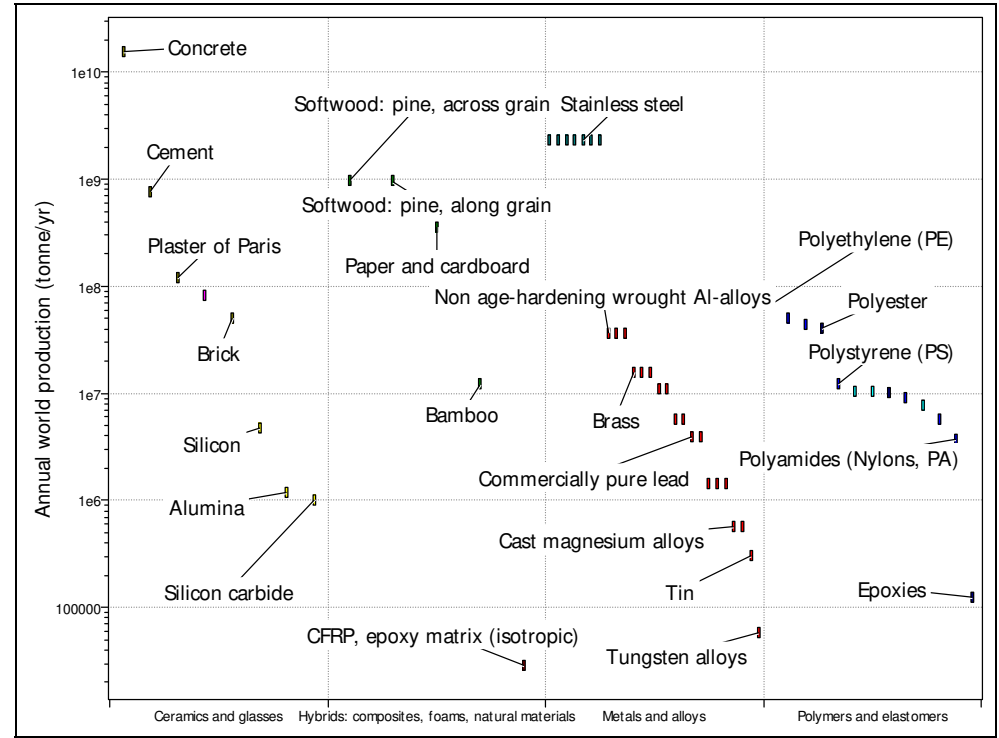

Fig. 1. Annual world production for principal materials

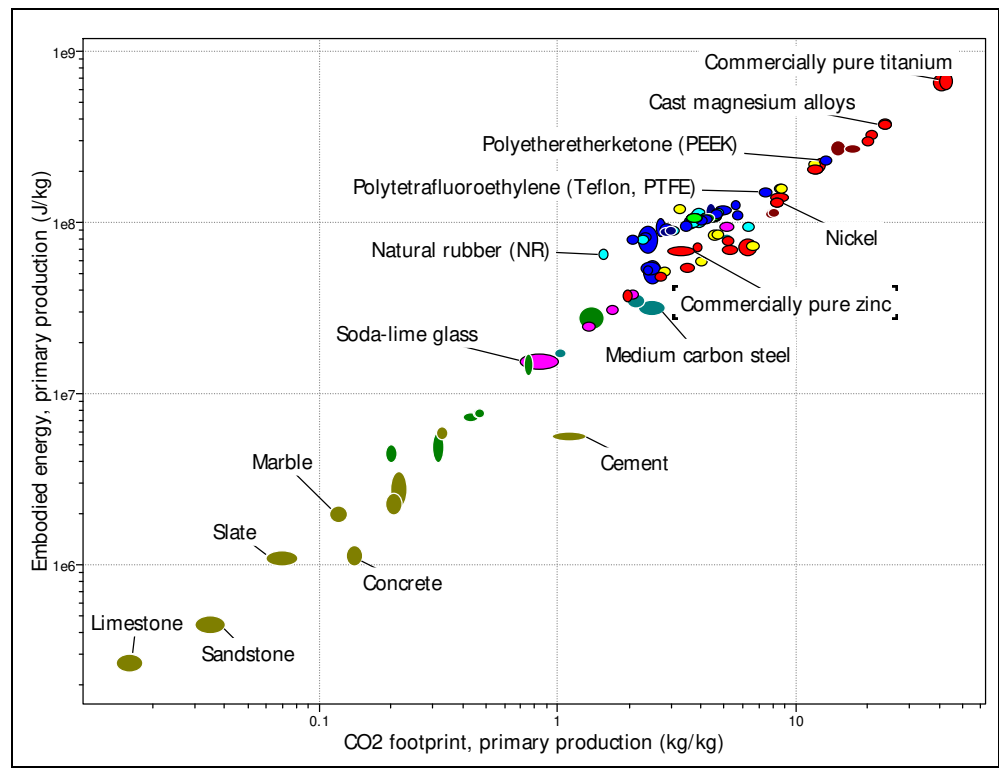

Fig. 2. Embodied Energy and $\mathrm{CO} 2$ footprint - primary production of principle materials

To select an eco friendly and sustainable material, one need to examine first the materials life cycle and consider how to apply life cycle analysis (Ashby et al., 2007). The materials life cycle is sketched in Figure 3. Ore and feedstock are mined and processed to yield materials. These materials are manufactured into products that are used and at the end of life, 
discarded, recycled or (less commonly) refurbished and reused. Energy and materials are consumed in each phase (material, manufacturing, use, transportation and disposal) of life, generating waste heat and solid, liquid, and gaseous emissions (Ashby et al., 2007). The results of the eco audit or life cycle analyis is shown in Figure 4. The results of the life cycle analysis will reveal the dominant phase that is consuming more energy or producing high $\mathrm{CO} 2$ emission. The next step is to separate the contributions of the phases of life because subsequent action depends on which is the dominant one. If it is that a material production, then choosing a material with low embodied energy is the way forward. But if it is the use phase, then choosing a material to make use less energy-intensive is the right approach even if it has a higher embodied energy.

This chapter introduces the methods and tools that will guide in the design analysis of the role of materials and processes selection in terms of embodied energy, carbon foot print, recycle fraction, toxicity and sustainability criteria. A particular skills need to be used by engineer or designer to guide design decisions that minimize or eliminate adverse eco impacts. Methods and tools that will guide in the design analysis of the role of materials and processes selection in terms of embodied energy, carbon foot print, recycle fraction, toxicity and sustainability criteria need to be used during the design process. Topics covered in this chapter will include: resource consumption and its drivers, materials of engineering, material property charts, the material life cycle, eco data, eco-informed material selection, and eco audits or life cycle analysis. The Cambridge Engineering Selecor software (Granta Design Limited, 2009) is used in this study for better understanding of these issues, create

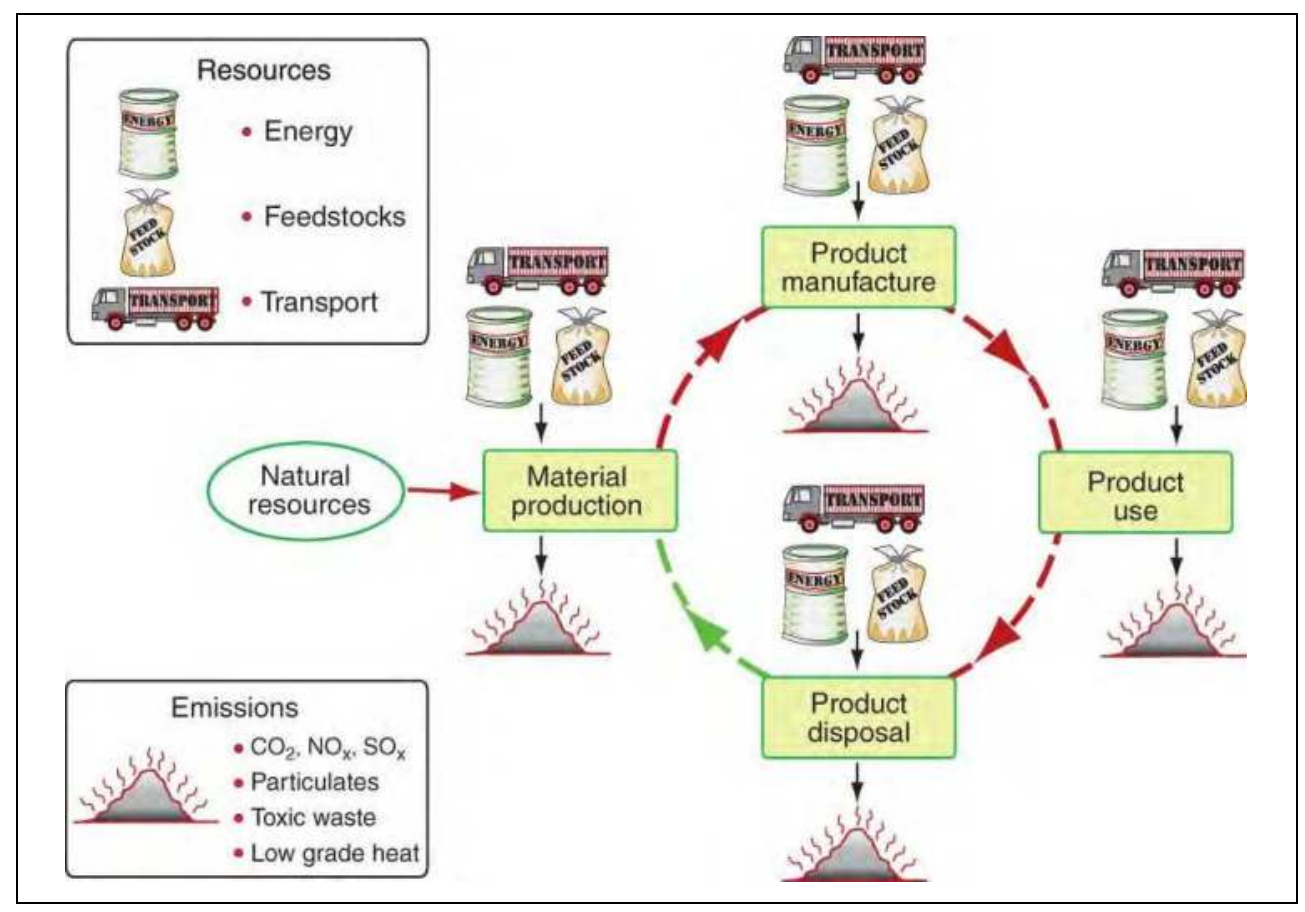

Fig. 3. Material Life Cycle (Ashby et al., 2007) 


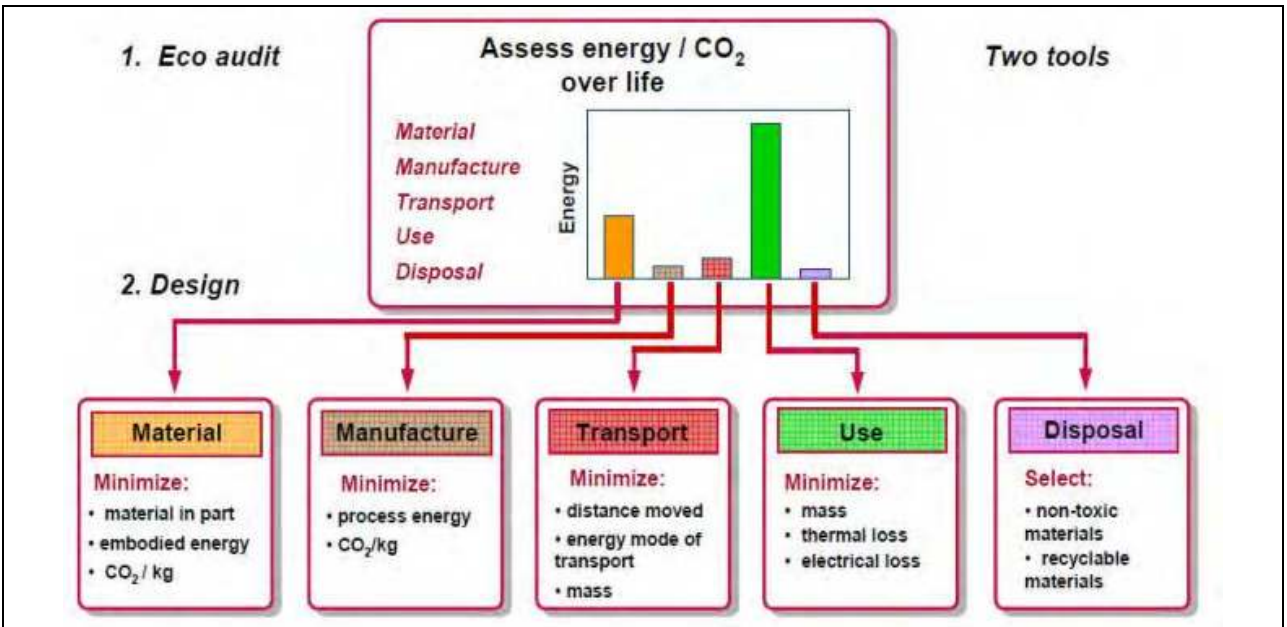

Fig. 4. Eco Audit and Eco Design (Ashby et al., 2007)

material charts, perform materials and processes selection, and eco audit or life cycle analysis allowing alternative design choices to meet the engineering requirements and reduce the environmental burden. The results of two case studies (material selection of desalination plant heat exchanger and life cycle analysis of patio heater) will be presented in this chapter book.

\section{Material and process families and eco data}

The common material properties are: general properties (cost and density), mechanical properties (strength, stiffness, toughness), thermal properties (conductivity, diffusivity, expansion, heat capacity), electrical properties (electrical conductivity, dielectric constant), optical (refraction, absorption), magnetic, and chemical properties (corrosion resistance). Materials properties determine the suitability of a material based on design requirements. A successful product, one that performs well, is good value for money and gives pleasure to the user uses the best materials for the job, and fully exploits its potential and characteristics. Materials selection is not about choosing a material, but a profile of properties that best meets the needs of the design (Ashby et al., 2007, and Alonso et al., 2007). Material and process are interdependent and grouped into families; each family has a characteristic profile (family likeness) which is useful to know when selecting which family to use for a design. In general, there are six families for materials (Ashby, 2005): metals (steels, cast irons, alloys...), ceramics (alumina, silicon carbides), polymers (polyethylene, polypropylene, polyethylene-terephthalate), glasses (soda glass, borosilicate glass), elastomers (isoprene, neoprene, butyl rubber, natural rubber) and hybrids (composites, foams) as shown in Figure 5.

Processes are also classified based on the design requirements (material, shape, dimensions, precision, and the number of parts to be made). The process families (Ashby, 2005) are: shaping (casting, molding, deformation, machining, heat treatment), joining (fastening, welding, adhesives) and surface treatments (polishing, painting) as shown in Figure 6. 


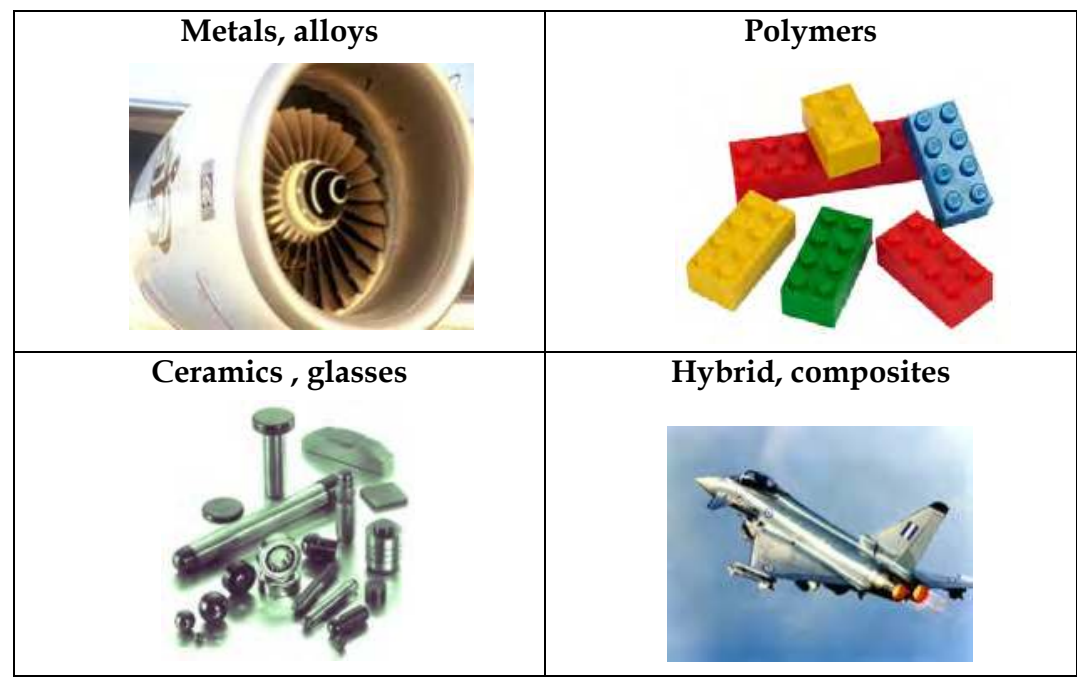

Fig. 5. Materials Families

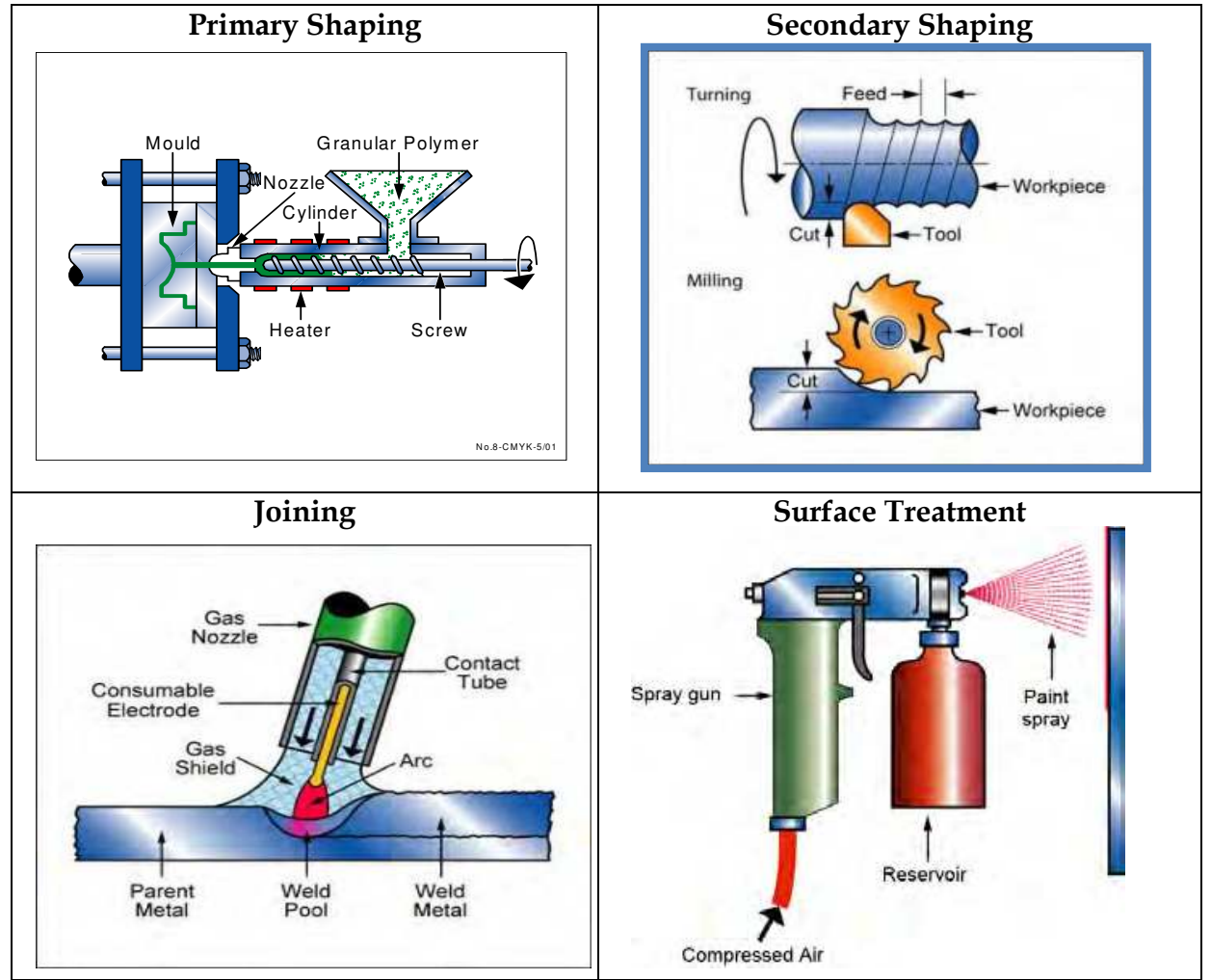

Fig. 6. Process Families 
The material and process selection based on some design requirements rely on the materials mechanical, thermal, electrical and chemical properties. Rational selection of materials to meet environmental objectives starts by identifying the phase of product-life that causes greatest concern: production, manufacture, use or disposal. Dealing with all of these requires data for the obvious eco-attributes such as energy, CO2 (Chapman, 1983) and other emissions, toxicity, ability to be recycled and the like (see table 1). Thus if material production is the phase of concern, selection is based on minimizing production energy or the associated emissions (CO2 production for example). But if it is the use-phase that is of concern, selection is based instead on light weight, excellence as a thermal insulator, or as an electrical conductor (while meeting other constraints on stiffness, strength, cost etc). Additional information such eco data (embodied energy and CO2 foot print as shown in Figure 2 and table 1) is needed for sustainable engineering and eco design.

\section{Geo-Economic Data for Principal Component}

\begin{tabular}{|l|l|l|}
\hline Annual world production & $21 \mathrm{e} 6-23 \mathrm{e} 6$ & tonne/year \\
\hline Reserves & $2 \mathrm{e} 10-2.2 \mathrm{e} 10$ & tonne \\
\hline Typical exploited ore grade & $30-34$ & $\%$ \\
\hline
\end{tabular}

Material Production - Energy and Emissions

\begin{tabular}{|l|l|l|}
\hline Production energy & $190-210$ & $\mathrm{MJ} / \mathrm{Kg}$ \\
\hline CO2 & $12-13$ & $\mathrm{~kg} / \mathrm{kg}$ \\
\hline NOX & $72-79$ & $\mathrm{~g} / \mathrm{kg}$ \\
\hline SOX & $120-140$ & $\mathrm{~g} / \mathrm{kg}$ \\
\hline
\end{tabular}

Indicators for Principal Component

\begin{tabular}{|l|l|l|}
\hline Eco indicator & $740-820$ & mmillions points $/ \mathrm{kg}$ \\
\hline
\end{tabular}

\section{End of life}

\begin{tabular}{|l|l|l|}
\hline Recycle & True & \\
\hline Down cycle & True & \\
\hline Biodegrade & False & \\
\hline Incinerate & False & \\
\hline Landfill & True & \\
\hline Recycle as fraction & $34-38$ & $\%$ \\
\hline
\end{tabular}

\section{Bio Data}

\begin{tabular}{|l|l|l|}
\hline Toxicity rating & Non toxic & \\
\hline $\begin{array}{l}\text { Approve for skin and food } \\
\text { contact }\end{array}$ & True & \\
\hline
\end{tabular}

\section{Sustainability}

\begin{tabular}{|l|l|l|}
\hline Sustainable material & No & \\
\hline
\end{tabular}

Table 1. Eco Data - Wrought Aluminium Pure 


\section{Life cycle analysis and selection strategies}

The material life cycle is shown in Figure 3. Ore and feedstock, drawn from the earth's resources, are processed to give materials. These materials are manufactured into products that are used, and, at the end of their lives, discarded, a fraction perhaps entering a recycling loop, the rest committed to incineration or land-fill (Gabi, 2008, Graedel, 1998, and Kickel, 2009) Energy and materials are consumed at each point in this cycle (phases), with an associated penalty of $\mathrm{CO} 2, \mathrm{SOx}, \mathrm{NOx}$ and other emissions, heat, and gaseous, liquid and solid waste. These are assessed by the technique of life-cycle analysis (LCA) (Ashby, 2007).

\subsection{The steps for life cycle analysis are:}

1. Define the goal and scope of the assessment: Why the assessment needs to be done? What is the subject and which part of its life are assessed?

2. Compile an inventory of relevant inputs and outputs: What resources are consumed? (bill of materials) What are the emissions generated?

3. Evaluate the potential impacts associated with those inputs and outputs

4. Interpretation of the results of the inventory analysis and impact assessment phases in relation of the objectives of the study: What the result means? What needs to be done about them?

The study examine the energy and material flows in raw material acquisition; processing and manufacturing; distribution and storage (transport, refrigeration...); use; maintenance and repair; and recycling options.

\subsection{The strategy for guiding design}

The first step is to develop a tool that is approximate but retains sufficient discrimination to differentiate between alternative choices. A spectrum of levels of analysis exist, ranging from a simple eco-screening against a list of banned or undesirable materials and processes to a full life cycle analysis, with overheads of time and cost.

The second step is to select a single measure of eco-stress. On one point there is some international agreement: the Kyoto Protocol of 1997 committed the developed nations that signed it to progressively reduce carbon emissions, meaning CO2 (Kyoto Protocol, 1999). At the national level the focus is more on reducing energy consumption, but since the energy consumption and $\mathrm{CO} 2$ production are closely related, they are nearly equivalent. Thus there is certain logic in basing design decisions on energy consumption or $\mathrm{CO} 2$ generation; they carry more conviction than the use of a more obscure indicator. We shall follow this route, using energy as our measure.

The third step is to separate the contributions of the phases (material, manufacturing, use, transportation and disposal) of life because subsequent action depends on which is the dominant one with respect of energy consumption and $\mathrm{CO} 2$ emissions (see Figure 4).

For selection to minimize eco-impact we must first ask: which phase of the life cycle of the product under consideration makes the largest impact on the environment? The answer guides material selection. To carry out an eco-audit or life cycle analysis we need the bill of material, shaping or manufacturing process, transportation used of the parts of the final product, the duty cycle during the use of the product, and also the eco data for the energy and $\mathrm{CO} 2$ footprints of materials and manufacturing process. 


\section{Results}

Two case studies of sustainable engineering and eco design are presented in this chapter book. The first case study deals with material selection for the condenser used in desalination plant (sustainable material). The question is what is the best material that can be used for the condenser based on some constraints and design objectives? The second case study is about the life cycle analysis of patio heater. The question is what the dominant phase of the life cycle of this product that is consuming more energy and producing more $\mathrm{CO} 2$ emissions?

\subsection{Case study 1: Material selection for desalination plant heat exchanger}

Desalination of seawater is one of the most promising techniques used to overcome water shortage problems (Nafey et al., 2004). The desalination techniques include thermal desalination processes (Multi Stage Flash - MSF, Multi Effect Distillation - MED) and membrane desalination processes (reverse osmosis - RO and Electro-Dialysis Reverse EDR). Multi Stage Flash (MSF) is one of he most commonly distillation process used for large-scale desalination of seawater (Hassan, 2003). In the MSF process, the seawater enters the evaporation chamber resulting in flash boiling of a fraction of the seawater. The vapour produced by flashing is then conveyed to the heat recovery section where it is condensed. Heat exchanger (evaporator and condensers) tubes represent the largest item in an MSF plant and not surprisingly more than $70 \%$ of the corrosion failures in desalination plants are attributed to heat exchange tubes. Heat exchangers tubes handle two fluids of completely different properties (seawater and vapors). It is one of the severest environments from the point of view of corrosion (Anees et al., 1993, and Aness et al., 1992). This study focuses only on the desalination plant condensers. The condenser is a sea water-cooled shell and tube heat exchanger installed in the exhaust steam from the evaporator in thermal desalination plant. The condenser is a heat exchanger that converts the steam received from the evaporator to liquid using the sea water as the cooling fluid. The key properties of the desalination plant surface condenser are: (1) heat transfer properties (thermal conductivity, convective heat transfer coefficients for steam and sea water, and fouling coefficients); (2) the erosion resistance (to steam for the external surface of the tube, and to raw sea waters which may contain sand and show turbulences for the internal surface of the tube); (3) corrosion resistance (to raw sea waters, steam and condensate). The heat transfer performance of the condenser is linked to the material selection - thermal conductivity, thickness, and the erosion/corrosion resistance of the tubing materials.

A condenser with high tubing thermal conductivity, thin wall tubing, and tubing surface that do not corrode in the heat exchanger environment and remains relatively cleans during the desalination process will provide excellent heat transfer performance. The principal objective of this study is to select the best materials for the condenser tubing (sustainable material) that will provide excellent thermal heat transfer performance, low cost and low embodied energy (sustainable energy) and CO2 foot print (sustainable environment).

The condenser shown in Figure 7 takes heat from the steam and passes it to the sea cooling water. The steam enters the shell at temperature $T_{V}$, changes its phase from gas to liquid during the heat transfer with the sea cooling water and exit the heat exchanger as condensate at temperature $\mathrm{T}_{\mathrm{C}}$. The sea water cooling fluid enters the condenser tubes at 

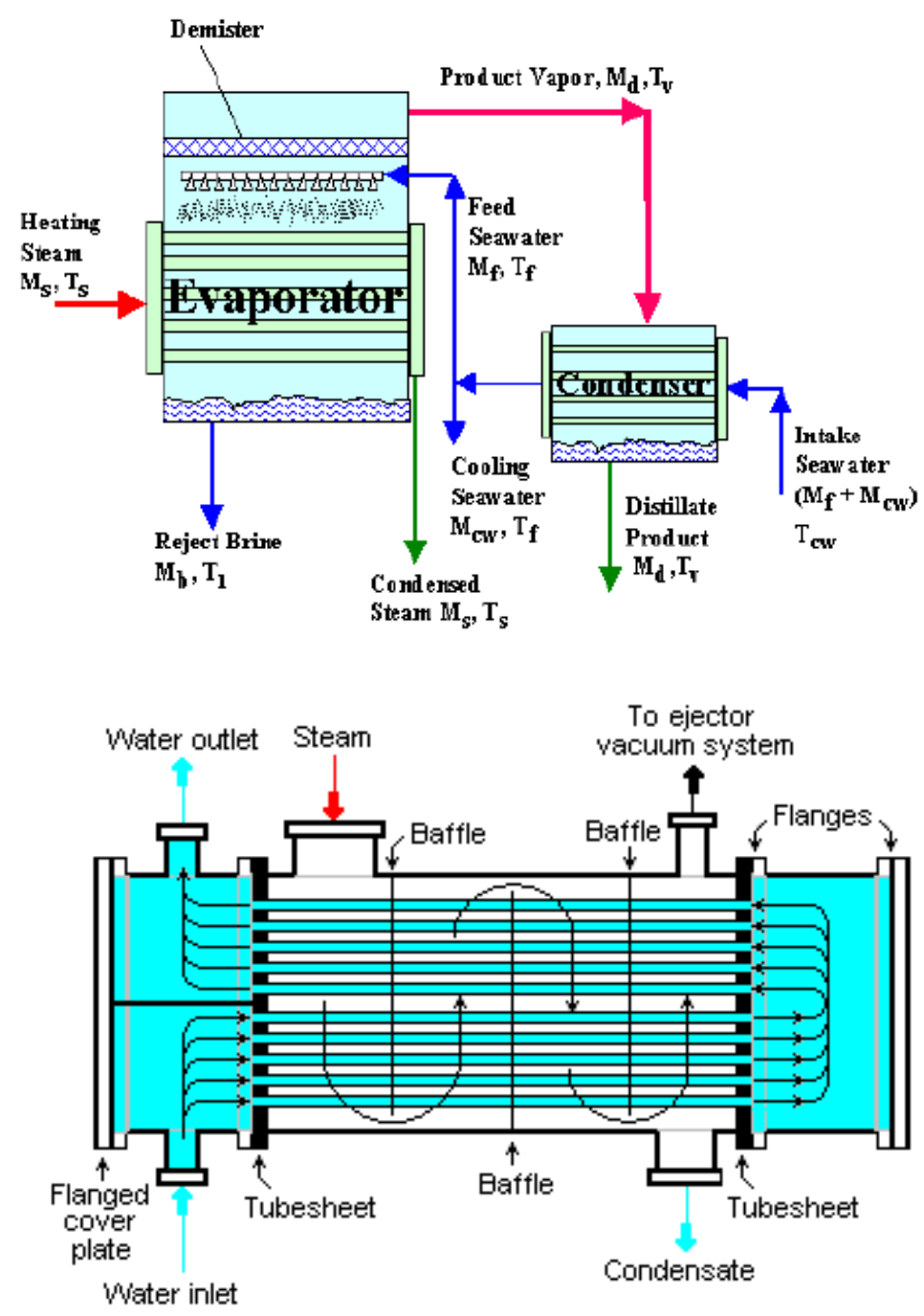

Fig. 7. Desalination process and heat exchanger (condenser)

temperature $\mathrm{T}_{\mathrm{CW}}$ and exit at high temperature $\mathrm{T}_{\mathrm{HW}}$. A key element in all heat exchangers is the tube wall or membrane which separates the sea water and the steam. It is required to transmit heat and there is frequently a pressure difference across it $\Delta \mathrm{p}$ (pressure difference between the sea water and the steam pressures). The question is what are the best materials for making these condensers? What are the best condenser materials that can provide high thermal conductivity but at the same time can sustain this pressure difference? What is the performance index that can be use for heat exchanger or condensers? The heat transfer from the steam to the sea water through the membrane or the thin wall involves convective transfer from steam to outside surface of the condenser tubes, conduction through the tube 
wall, and convection again to transfer the heat to sea water. The heat flux $q$ into the tube wall by convection $\left(\mathrm{W} / \mathrm{m}^{2}\right)$ is described by the heat transfer equation $\mathrm{q}=\mathrm{h}_{1} \Delta \mathrm{T}_{1}$, where $\mathrm{h} 1$ is the heat transfer coefficient for the steam and $\Delta \mathrm{T} 1$ is the temperature drop across the surface from the steam into the outside tube wall. Conduction is described by the conduction equation; $\mathrm{q}=\left(\lambda \Delta \mathrm{T}_{12}\right) / \mathrm{e}$, where $\lambda$ is the thermal conductivity of the wall (thickness e) and $\Delta \mathrm{T} 12$ is the temperature difference across the tube wall. The heat flux q out from the tube wall by convection is described by the heat transfer equation $q=h_{2} \Delta T_{2}$, where $h_{2}$ is the heat transfer coefficient for sea water and $\Delta \mathrm{T}_{2}$ is the temperature drop from the inside surface of the tube to the sea water. The heat flux is also given by: $q=U\left(T_{V}-T_{C W}\right)$, where $U$ is the overall heat transfer coefficient and $\mathrm{T}_{\mathrm{V}}$ is the steam temperature entering the shell and $\mathrm{T}_{\mathrm{CW}}$ is the temperature of sea water entering the tube. The overall heat transfer coefficient is given by:

$$
U=\frac{1}{\frac{1}{h_{1}}+\frac{e}{\lambda}+\frac{1}{h_{2}}}
$$

The total heat flow is given by:

$$
Q=q A=\left(\frac{1}{\frac{1}{h_{1}}+\frac{e}{\lambda}+\frac{1}{h_{2}}}\right) A \quad\left(T_{V}-T_{C W}\right)
$$

One of the constraints of the heat exchanger is that the wall thickness must be sufficient to support the pressure difference $\Delta \mathrm{p}$. This requires that the stress in the wall remain below the elastic limit (yield strength): $\sigma=\frac{\Delta p r}{e}<\sigma_{e l}$.

Where $\mathrm{r}$ is the pipe radius and $\mathrm{e}$ is the pipe thickness.

The heat flux is given by:

$$
\frac{Q}{A}=q=\left(\frac{1}{\frac{1}{h_{1}}+\frac{\Delta p r}{\lambda \sigma_{e l}}+\frac{1}{h_{2}}}\right) \quad\left(T_{V}-T_{C W}\right)
$$

The heat flow per unit area of tube wall, Q/A or $\mathrm{q}$ is maximized by maximizing the performance index $\mathrm{M}$ given by $M=\lambda \sigma_{e l}$. The maximum value of $\mathrm{M}$ is obtained by minimizing the tube wall thickness or maximizing both the thermal conductivity and the yield strength.

Selecting materials for desalination plant heat exchanger involves seeking the best match between design requirements and the properties of the materials that may be used to make the heat exchanger. The strategy for selecting the material for desalination plant heat exchangers is: 
a. Translate design requirements: develop a list of requirements the material must meet, expressed as function (what does the system do), objectives (what is to be maximized or minimized), constraints (what nonnegotiable conditions must met) and free variables (what parameters of the problem is the designer free to change). The main function of the condenser is to exchange heat between the steam and seat water (heat exchanger) and to convert the steam to distilled water. The objectives are to maximize heat flow per unit area, minimize the cost and eco friendly materials (minimize the energy and the $\mathrm{CO} 2$ footprint). The constraints for the condenser are: (a) operating temperature up to $150^{\circ} \mathrm{C}$; (b) support pressure difference $\Delta \mathrm{p},(\mathrm{c})$ excellent resistance to sea water, (d) very high resistance of the material to pitting and crevice corrosion, and (e) excellent resistance of the material stress corrosion cracking. The free choices for the condenser design are the choice of material.

b. Screening: After developing the list of requirements the material must meet, the next step is to eliminate the materials that can not do the job because one or more their attributes lies outside the limits set by the constraints. The limit and tree stages of the Cambridge selector software (Granta Design Limited, 2009) are used in this study as selection tools for the screening process. The limit stage applies numeric and discrete constraint. Required lower or upper limits for material properties are entered into the limit stage property boxes. If a constraint is entered in the minimum box, only materials with values greater than the constraint are retained. If it is entered in the Maximum box, only materials with smaller values are retained. The graph option can be used to create bar charts and bubble charts. A box selection isolates a chosen part of a chart. Any material bar or bubble lying in, or overlapping the box is selected and all others are rejected. The line selection divides a bubble chart into two regions. The user is free to choose the slope of the line, and to select the side on which materials are to be chosen. This allows selection of materials with given values of combinations of material properties such as E/ $\rho$, where E is Young's modulus and $\rho$ is density. The tree stage allows the search to be limited to either: a subset of materials (metals, hybrids, polymers, and ceramics) or materials that can be processes in chosen ways (manufacturing process).

c. Ranking: Find the screening materials that do the job best. Rank the materials that survive the screening using the criteria of excellence or the objectives and make the final materials choice.

Figure 8 shows the results of the screening process for the performance index M. Only 16 materials passed the test based on the design requirements (operating temperature $>150 \mathrm{C}$, resistance to sea water, resistance to pitting and crevice corrosion, and excellent resistance to stress corrosion cracking). Based on the objectives (maximize heat flux, minimize the cost, the embodied energy and $\mathrm{CO} 2$ foot print) set during the design process, it is clear that the best material that can be used for the desalination plant condenser is the stainless steel duplex UNS S32550, wrought. It has the maximum value for performance index $M$ (high thermal conductivity and thin tube wall), and lowest cost $(14-14 \$ / \mathrm{Kg})$ as shown in Figure 8 . In addition to that this material has the lowest embodied energy and $\mathrm{CO} 2$ foot print as shown in Figure 9. The characteristics of the selected material for the desalination plant condenser are summarized in Table 2. 


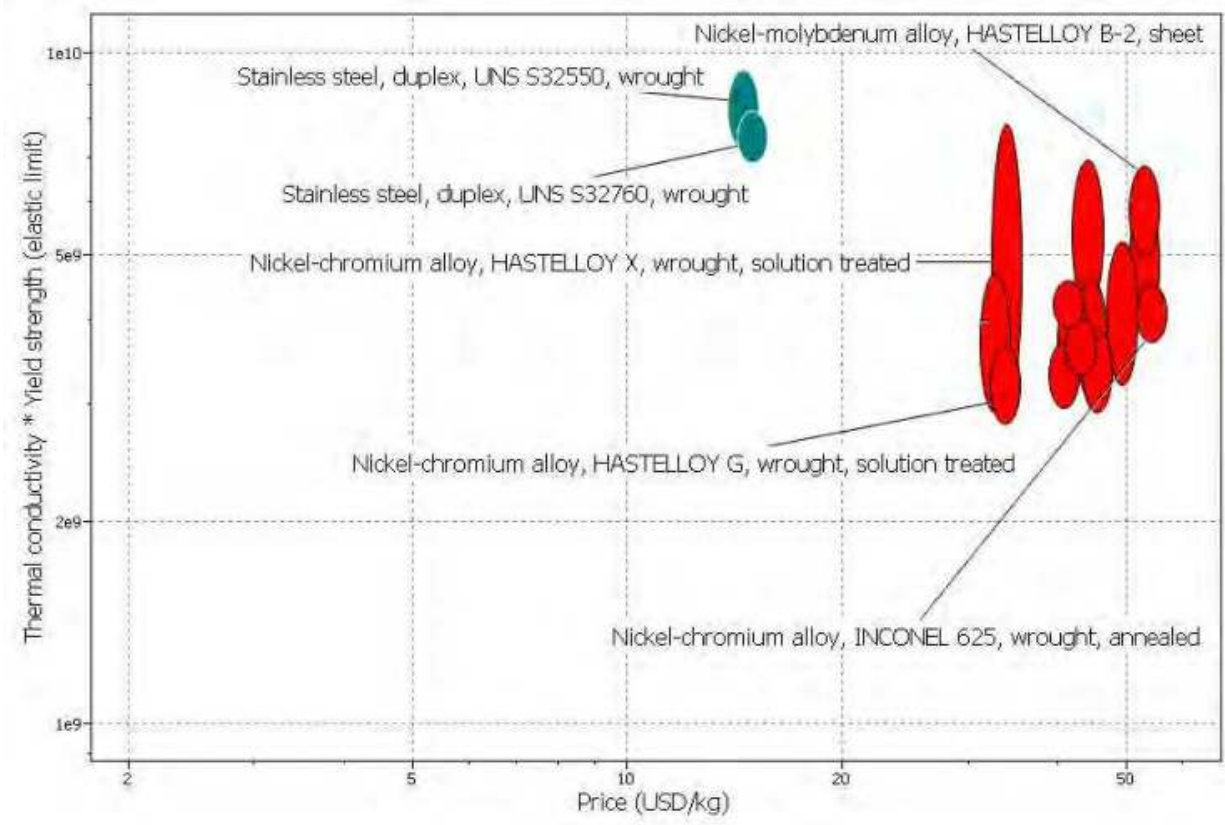

Fig. 8. Results of the Screening Process - Performance Index M versus Material Cost

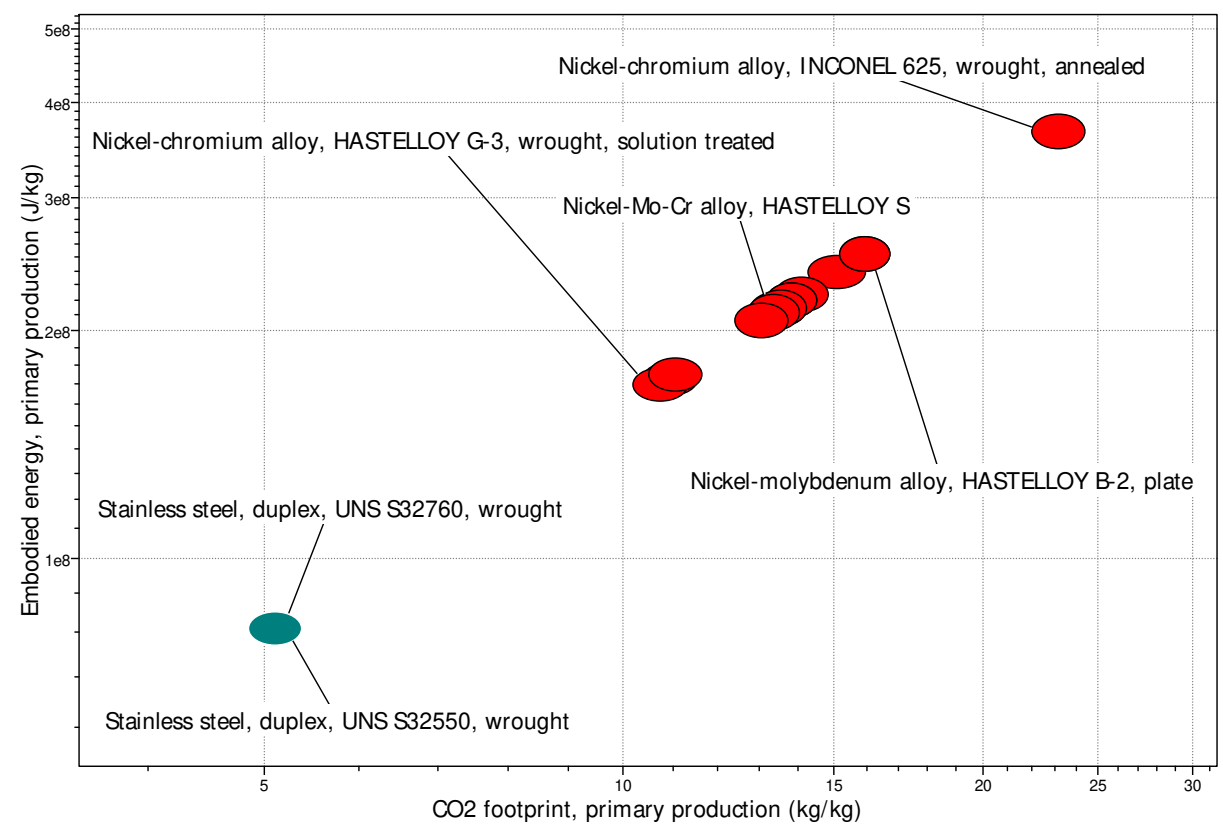

Fig. 9. Results of the Screening Process - Embodied Energy versus the CO2 foot print 


\begin{tabular}{|c|c|c|c|c|c|c|}
\hline Material & $\begin{array}{c}\text { Performance } \\
\text { Design } \\
M=\lambda \sigma_{e l}\end{array}$ & $\begin{array}{c}\text { Price } \\
\$ / \mathrm{Kg}\end{array}$ & $\begin{array}{c}\text { Pitting and } \\
\text { Crevice } \\
\text { Corrosion }\end{array}$ & $\begin{array}{c}\text { Stress } \\
\text { Corrosion } \\
\text { Cracking }\end{array}$ & $\begin{array}{c}\text { Embodied } \\
\text { Energy } \\
(\mathrm{J} / \mathrm{Kg})\end{array}$ & $\begin{array}{c}\text { Maximum } \\
\text { Service } \\
\text { Temp. (C) }\end{array}$ \\
\hline $\begin{array}{c}\text { 1. Stainless } \\
\begin{array}{c}\text { UNS S32550, } \\
\text { wrought }\end{array}\end{array}$ & $7.3 \mathrm{e} 9-9.4 \mathrm{e} 9$ & $13.2-15.2$ & Very High & Excellent & $7.7 \mathrm{e}-8.5 \mathrm{e} 7$ & $335-365$ \\
\hline $\begin{array}{c}\text { 2. Stainless } \\
\text { Steel, Duplex } \\
\begin{array}{c}\text { UNS S32760, } \\
\text { wrought }\end{array}\end{array}$ & $6.9 \mathrm{e} 9-8.1 \mathrm{e} 9$ & $14.2-15.7$ & Very High & Excellent & $7.7 \mathrm{e}-8.5 \mathrm{e} 7$ & $335-365$ \\
\hline
\end{tabular}

Table 2. Selected Materials for the desalination plant condenser

\subsection{Case Study 2: Life cycle analysis of patio heater}

An eco audit is a fast initial assessment. It identifies the phases of life - material, manufacture, transport, and use - that carry the highest demand for energy or create the greatest burden of emissions. It points the finger, so to speak, identifying where the greatest gains might be made. Often, one phase of life is, in eco terms, overwhelmingly dominant, accounting for $60 \%$ or more of the energy and carbon totals. This difference is so large that the imprecision in the data and the ambiguities in the modeling, are not an issue; the dominance remains even when the most extreme values are used. It then makes sense to focus first on this dominant phase, since it is here that the potential innovative material choice to reduce energy and carbon are greatest.

An energy and $\mathrm{CO} 2$ eco audits were performed for the patio heater shown in Figure 10. It is manufactured in Southeast Asia and shipped 8,000 Km to the United States, where it is sold and used. It weighs $24 \mathrm{~kg}$, of which $17 \mathrm{~kg}$ is rolled stainless steel, $6 \mathrm{~kg}$ is rolled carbon steel, $0.6 \mathrm{~kg}$ is cast brass and $0.4 \mathrm{~kg}$ is unidentified injection-molded plastic (See Materials - Tables 3 and 4). During the use, it delivers $14 \mathrm{~kW}$ of heat ("enough to keep 8 people warm") consuming $0.9 \mathrm{~kg}$ of propane gas (LPG) per hour, releasing $0.059 \mathrm{~kg}$ of CO2 / MJ.

The heater is used for 3 hours per day for 30 days per year, over 5 years, at which time the owner tires of it and takes it to the recycling depot (only 6 miles / $10 \mathrm{~km}$ away, so neglect the transport CO2) where the stainless steel, carbon steel and brass are sent for recycling (See end of life - Tables 3 and 4). These data are used to construct a bar-chart for energy and $\mathrm{CO} 2$ emission over the life of the patio heater.

The table (See Figure 10) lists the energy and carbon footprints of the materials and manufacturing processes for the patio heater. The bar chart plots the totals for each phase. For the sea transport over $8000 \mathrm{~km}$, the energy consumed is $30.7 \mathrm{MJ}$ and the CO2 released is $2.18 \mathrm{~kg}$ of carbon dioxide, so small as to be invisible on the bar chart. The results show that $97.9 \%$ of the energy consumed and $98.1 \%$ of the CO2 emitted are during the use phase. The energy consumed and $\mathrm{CO} 2$ emitted for the material phase are respectively $5.9 \%$ and $5.2 \%$. The results also show that $4.1 \%$ of the energy can be recovered and $3.7 \%$ reduction of $\mathrm{CO} 2$ emission can be obtained by recycling the parts of the patio heater. A detailed breakdown of the energy and $\mathrm{CO} 2$ foot print for individual life phases (material, manufacture, transport, use, and end of life) are shown respectively in Tables 3 and 4. 
Energy and $\mathrm{CO} 2$ Footprint Summary:

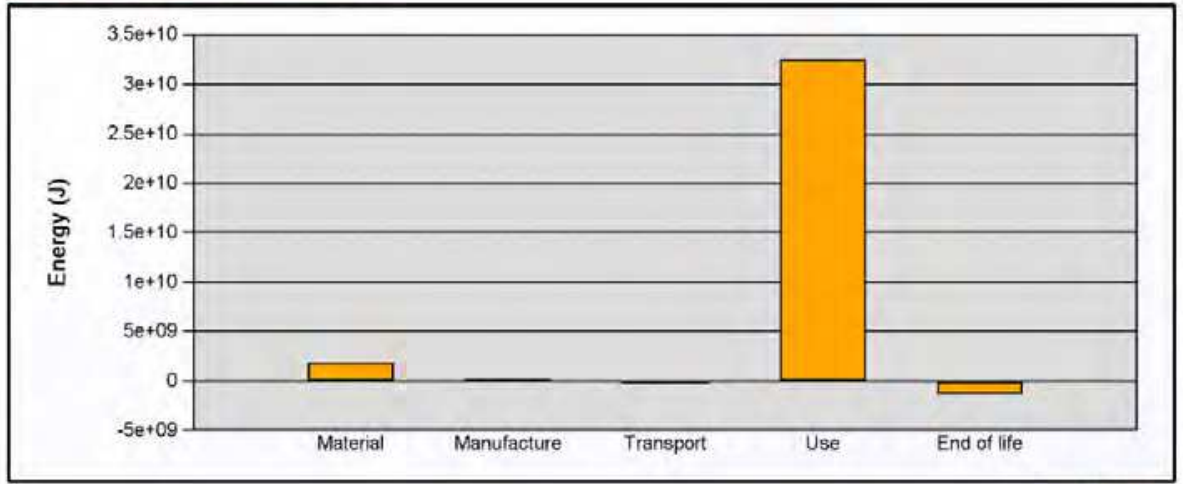

Energy Details...

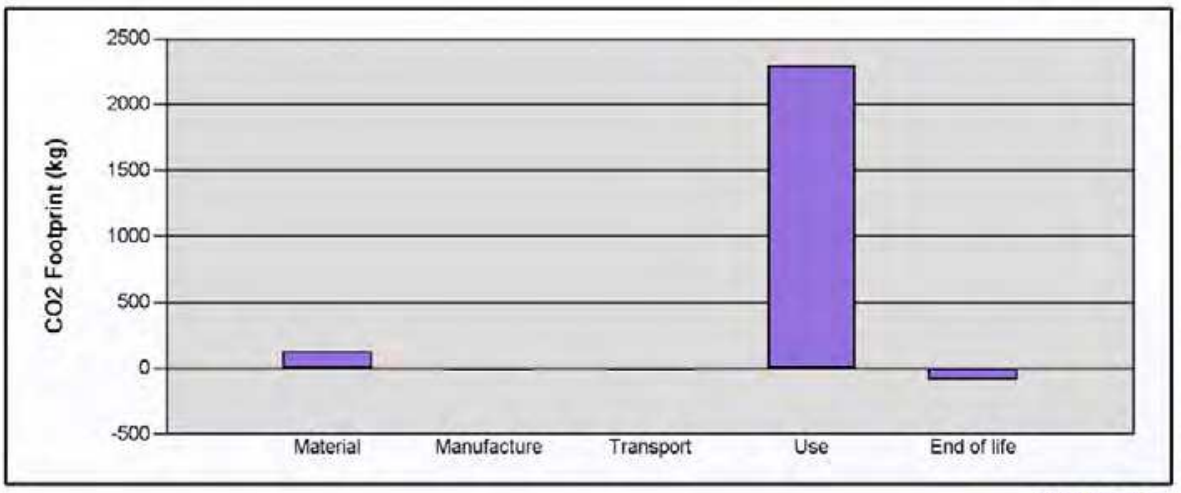

CO2 Details....

\begin{tabular}{|l|c|c|c|c|}
\hline Phase & Energy $(\mathrm{J})$ & Energy $(\%)$ & $\operatorname{CO2}(\mathrm{kg})$ & $\operatorname{CO2}(\%)$ \\
\hline Material & $1.94 \mathrm{e}+09$ & 5.9 & 123 & 5.2 \\
\hline Manufacture & $8.41 \mathrm{e}+07$ & 0.3 & 6.7 & 0.3 \\
\hline Transport & $3.07 \mathrm{e}+07$ & 0.1 & 2.18 & 0.1 \\
\hline Use & $3.24 \mathrm{e}+10$ & 97.9 & $2.3 \mathrm{e}+03$ & 98.1 \\
\hline End of life & $-1.36 \mathrm{e}+09$ & -4.1 & -86.2 & -3.7 \\
\hline Total & $3.31 \mathrm{e}+10$ & 100 & $2.35 \mathrm{e}+03$ & 100 \\
\hline
\end{tabular}

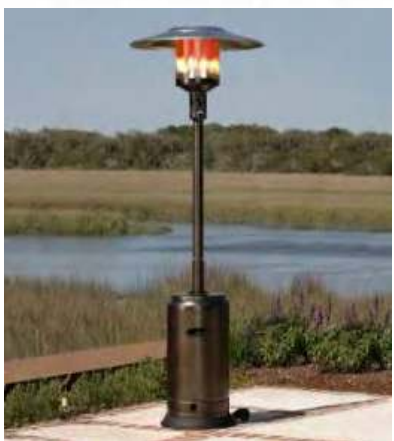

Fig. 10. Life Cycle Analysis of Patio Heater: Energy and CO2 Footprint Analysis 


\begin{tabular}{|c|c|c|c|c|c|c|c|c|}
\hline \multirow{7}{*}{ Material } & \multicolumn{8}{|c|}{ Breakdown by component } \\
\hline & Component & \multicolumn{2}{|c|}{ Material } & $\begin{array}{l}\text { Recycie } \\
\text { content }\end{array}$ & $\begin{array}{l}\text { Material } \\
\text { Embodiod } \\
\text { Energy: } \\
\text { (Hikgl }\end{array}$ & \begin{tabular}{|c|c|} 
Total \\
Mass $(\mathrm{kg})$ \\
\end{tabular} & Energy (J) & $\%$ \\
\hline & Component 1 & \multicolumn{2}{|c|}{$\begin{array}{l}\text { Stainless steel, duplex, } \\
\text { ASTM CD-AUCu Cast }\end{array}$} & Virgin (os) & 8. $10+07$ & 17 & $1.40+09$ & 71.1 \\
\hline & Component 2 & \multicolumn{2}{|c|}{ 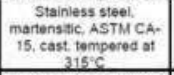 } & $\operatorname{Vingin}(0 \mathrm{~s})$ & $8.10+07$ & 6 & $4.96+08$ & 25,1 \\
\hline & Compoent 3 & \multicolumn{2}{|c|}{$\begin{array}{l}\text { Brass. Cuzn 10pb3sn2. } \\
\text { andicast }\end{array}$} & Virgin (0)s) & $70+07$ & 0.6 & $4.2 e+07$ & 2.2 \\
\hline & Component 4 & \multicolumn{2}{|c|}{$\begin{array}{c}P P(65-70 \% \text { barium } \\
\text { guttente }\end{array}$} & Virgin (00) & $7,7 e+07$ & 0.4 & 3.10+07 & 1.6 \\
\hline & Total & & & & & 24 & $1.9 e+09$ & 100 \\
\hline \multirow{7}{*}{ Manufacture } & \multicolumn{8}{|c|}{ Breakdown by component } \\
\hline & Component & \multicolumn{3}{|c|}{ Process: } & $\begin{array}{l}\text { Processing } \\
\text { Energy (Jikg) }\end{array}$ & $\begin{array}{c}\text { otal Mass } \\
(\mathrm{kg})\end{array}$ & Energy (J) & $*$ \\
\hline & Component 1 & & 29. roing & & $6+06$ & 17 & $50+07$ & 59.5 \\
\hline & Component 2 & & ng roling & & $0+\infty 6$ & 6 & $250+07$ & 29.6 \\
\hline & Compoent 3 & & uting & & $6+06$ & 0.6 & $1.60 \div 06$ & 1.9 \\
\hline & Component 4 & Poiy & tmoiding & & $6+07$ & 0.4 & $7,64+06$ & 20 \\
\hline & Total & & & & & 24 & $8.4 e+07$ & 100 \\
\hline & Breakdown & Tot: & product & mass $=24 \mathrm{k}$ & & & & \\
\hline & stage Name & Tran & sort Type & & 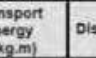 & stance $(m)$ & Energy (J) & $\mathrm{x}$ \\
\hline & & & freight & & 216 & $80+06$ & $3.16 \div 07$ & 100.0 \\
\hline & Total & & & & & $80+06$ & $3.10+07$ & 100 \\
\hline Transport & Breakdown & Tot: & transpo & It distance $=$ & $3 e+06 \mathrm{~m}$ & & & \\
\hline & Component & Tota & Vass $(\mathrm{kg})$ & & $\operatorname{cog}(\pi)$ & $x$ & & \\
\hline & Component 1 & & 17 & & $6 * 07$ & 70.8 & & \\
\hline & Component 2 & & 5 & & $a+06$ & 250 & & \\
\hline & Compoent 3 & & 0.5 & & $6+05$ & 2.5 & & \\
\hline & Component 4 & & 0.4 & & $6+05$ & 17 & & \\
\hline & Tolal & & 24 & & $0+07$ & 100 & & \\
\hline & Relative & of stat & and $\mathrm{r}$ & mobile $\mathrm{m}$ & des & & & \\
\hline & Mode & & & Energy & & & $\%$ & \\
\hline & Static & & & $3.2 \mathrm{e}+$ & & & 100.0 & \\
\hline & Mobile & & & 0 & & & & \\
\hline & Total & & & $3.2 \mathrm{e}+$ & & & 100 & \\
\hline & Static M & & & & & & & \\
\hline & Energy ins & Type & $\begin{array}{r}\text { Fossil } \\
\text { ve }\end{array}$ & $\begin{array}{l}\text { fuel to them } \\
\text { nted system }\end{array}$ & & & & \\
\hline & Product E & & & 0.7 & & & & \\
\hline & Use Locat & & & hiled States & & & & \\
\hline & Energy Eq & $c e(J / J)$ & & 1 & & & & \\
\hline & Power Rat & & & 14 & & & & \\
\hline & Usage (ho & & & 3 & & & & \\
\hline & Usage (da & & & 30 & & & & \\
\hline & Product L & & & 5 & & & & \\
\hline & Total Life L & & & $4.5 e+02$ & & & & \\
\hline & Relative co & d of life of & ions & & & & & \\
\hline End of Life & Component: & & $\begin{array}{l}\text { The } \\
\text { Tute }\end{array}$ & $\begin{array}{l}\text { Collection } \\
\text { Energy }(J \times g)\end{array}$ & $\begin{array}{l}\text { Potential End } \\
\text { of Lite } \\
\text { Saving } 1 / 2 \mathrm{~kg} \\
\end{array}$ & $\begin{array}{c}\text { Total Mass } \\
(\mathrm{kg})\end{array}$ & $\begin{array}{l}\text { Total EoL } \\
\text { Energy (J) }\end{array}$ & $x$ \\
\hline & Component 1 & & 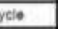 & $70+05$ & $5.86 * 07$ & 17 & $-9.8 e+08$ & 71.7 \\
\hline & Component 2 & & & $70+05$ & $-580+07$ & 6 & $-3.5 e+08$ & 25.3 \\
\hline & Compoent 3 & & ycit & $70+05$ & $.5 e+0 ?$ & 0.6 & $-2.96+07$ & 2.6 \\
\hline & Component 4 & & & $26+06$ & 0 & 0.4 & $84+04$ & 0.5 \\
\hline & Total & & & & & 24 & $+1,4 e+09$ & 100 \\
\hline
\end{tabular}

Table 3. Detailed Breakdown of individual life phases: Energy Analysis - Patio Heater 


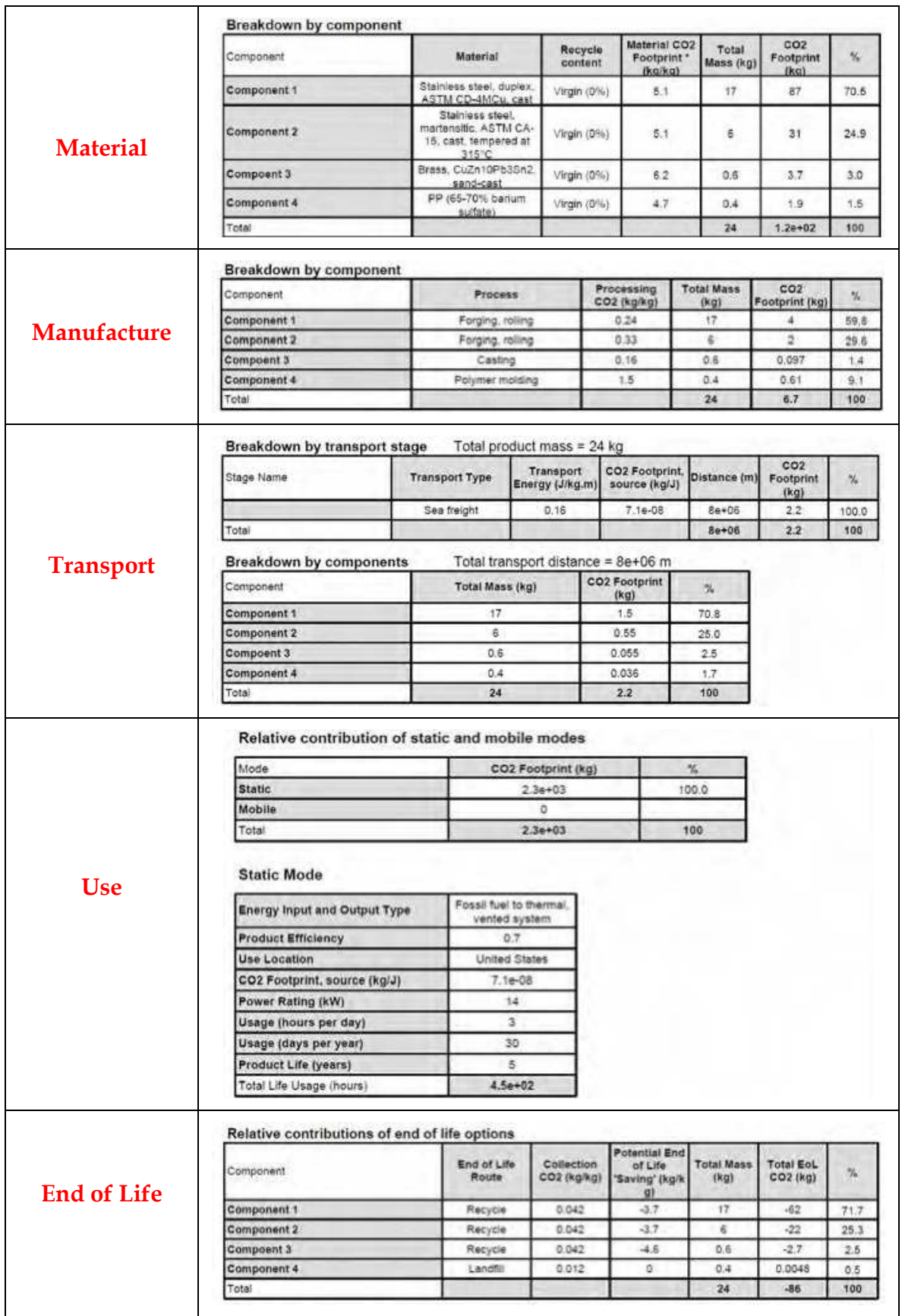

Table 4. Detailed Breakdown of individual life phases: CO2 Foot Print - Patio Heater 


\section{Conclusion}

The methods and tools presented in this book chapter, will guide in the design analysis of the role of materials and processes selection in terms of embodied energy, carbon foot print, recycle fraction, toxicity and sustainability criteria. A particular skills need to be used during the design process not only to satisfy the design requirements but also to minimize or eliminate adverse eco impacts (sustainable design). Two case studies of sustainable engineering and eco design are presented in this chapter book. The first case study deals with material selection for the condenser used in desalination plant and the second case study is about the life cycle analysis of patio heater. The results of the selection process for the heat exchanger (condenser) of a desalination plant show that the best material that can be used for the condenser is the stainless steel, duplex UNS S32255O, wrought. This material has (1) the highest design performance M (high heat flux), (2) the lowest cost (13 - 15 \$/ Kg), (3) a very good resistance to pitting and crevice resistance, (4) an excellent resistance to stress corrosion cracking (no breaks at high strengths or $>75 \%$ of yield strength in various environments), (5) excellent material resistance to sea water (no degradation in material performance expected after a long exposure to sea water), and (6) a good pitting resistance equivalent number (PREN $=40$ ). In addition the embodied energy (energy required to make $1 \mathrm{Kg}$ of the material) and the $\mathrm{CO} 2$ foot print (mass of $\mathrm{CO} 2$ released during the production of $1 \mathrm{Kg}$ of the material) are very low compared to the other materials. The second case study was about the life cycle analysis of the patio heater. The life cycle analysis strategy has two part: (1) an eco audit for a quick and approximate assessment of the distribution of energy demand and carbon emission over the patio heater's life; and (2) material selection to minimize the energy and carbon over the full life, balancing the influence of the choice over each phase of the life (selection strategies and eco informed material selection -suatianble design). The results of the life cycle analysis of patio heater show that the problem with the energy consumed and carbon foot print for the patio heater was during the use of the heater. A new materials can be selected to reduce the heat losses during the the use of the patio heater.

\section{References}

Alonso, E., Gregory, J., Field, F., Kirchain, R., (2007), Material availability and the supply chain: risks, effects, and responses'; Environmental Science and Technology, Vol 41, pp. 6649- 6656

Anees U Malik and P.C. Mayan Kutty, Corrosion and material selection in desalination plants, Presented to SWCC 0 \& M Seminar, Al Jubail, April 1992.

Anees U Malik, Saleh A. Al-Fozan and Mohammad Al Romiahl, Relevance of corrosion research in the materials selection for desalination plants, Presented in Second Scientific Symposium on Maintenance Planning and Operations, King Saud University, Riyadh, 24-26 April, 1993

Ashby, M.F. (2005) "Materials Selection in Mechanical Design", 3rd edition, ButterworthHeinemann, Oxford, UK, Chapter 16.

Ashby, M.F., Shercliff, H., and Cebon, D., (2007), “Materials: engineering, science, processing and design", Butterworth Heinemann, Oxford UK, Chapter 20. 
Chapman, P.F. and Roberts, F. (1983), Metal resources and energy; Butterworth's Monographs in Materials, Butterworth and Co, ISBN 0-408-10801-0

Fiksel, J., Design for Envirnment, (2009), A guide to sustianble product development, McGraw Hill, ISBN 978-0-07-160556-4

Gabi, PE International, (2008), www.gabi-sofwtare.com

Graedel, T.E. (1998), Streamlined life cycle assessment, prentice Hall, ISBN 0-13-607425-1

Granta Design Limited, Cambridge, (2009) (www.grantadesign.com), CES EduPack User Guide

Hassan E. S. Fath and Mohamed A. Ismail, Enhancement of chemical cleaning and brine heater condensate, Seventh International Water Technology Conference Egypt 1-3 April 2003

Kyoto protocol, United Nations, Framework Convention on Climate Change, (1997), Document FCCC/CP 1997/7/ADD.1

Nafey, A. S., Fath, H. E. S., Mabrouk, A. A., Elzzeky, M. A., A new visual package for simulation of thermal desalination processes: development and verification, Eighth International Water Technology Conference, IWTC8 2004, Alexandria, Egypt

Wolfe, J.A. (1984), Mineral resources: a worls review, Chapman \& Hall, ISBN 0-4122-5190-6 


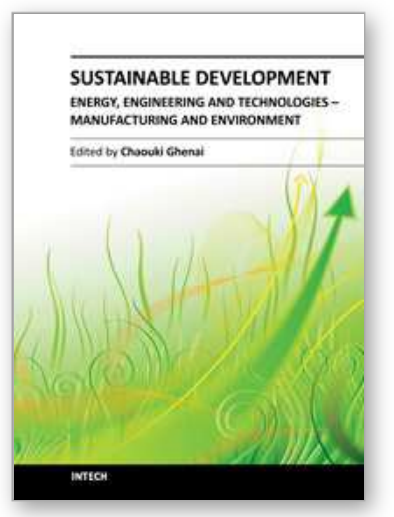

\author{
Sustainable Development - Energy, Engineering and Technologies \\ - Manufacturing and Environment \\ Edited by Prof. Chaouki Ghenai
}

ISBN 978-953-51-0165-9

Hard cover, 264 pages

Publisher InTech

Published online 29, February, 2012

Published in print edition February, 2012

The technological advancement of our civilization has created a consumer society expanding faster than the planet's resources allow, with our resource and energy needs rising exponentially in the past century. Securing the future of the human race will require an improved understanding of the environment as well as of technological solutions, mindsets and behaviors in line with modes of development that the ecosphere of our planet can support. Some experts see the only solution in a global deflation of the currently unsustainable exploitation of resources. However, sustainable development offers an approach that would be practical to fuse with the managerial strategies and assessment tools for policy and decision makers at the regional planning level. Environmentalists, architects, engineers, policy makers and economists will have to work together in order to ensure that planning and development can meet our society's present needs without compromising the security of future generations.

\title{
How to reference
}

In order to correctly reference this scholarly work, feel free to copy and paste the following:

Chaouki Ghenai (2012). Sustainable Engineering and Eco Design, Sustainable Development - Energy, Engineering and Technologies - Manufacturing and Environment, Prof. Chaouki Ghenai (Ed.), ISBN: 978-95351-0165-9, InTech, Available from: http://www.intechopen.com/books/sustainable-development-energyengineering-and-technologies-manufacturing-and-environment/sustainable-engineering-and-eco-design-

\section{INTECH}

open science | open minds

\author{
InTech Europe \\ University Campus STeP Ri \\ Slavka Krautzeka 83/A \\ 51000 Rijeka, Croatia \\ Phone: +385 (51) 770447 \\ Fax: +385 (51) 686166 \\ www.intechopen.com
}

\author{
InTech China \\ Unit 405, Office Block, Hotel Equatorial Shanghai \\ No.65, Yan An Road (West), Shanghai, 200040, China \\ 中国上海市延安西路65号上海国际贵都大饭店办公楼 405 单元 \\ Phone: +86-21-62489820 \\ Fax: $+86-21-62489821$
}


(C) 2012 The Author(s). Licensee IntechOpen. This is an open access article distributed under the terms of the Creative Commons Attribution 3.0 License, which permits unrestricted use, distribution, and reproduction in any medium, provided the original work is properly cited. 